\title{
ANALISIS XEROSTOMIA TERHADAP KESEHATAN GIGI DAN MULUT TERKAIT KUALITAS HIDUP PADA LANSIA DI DESA MATTOMBONG KECAMATAN MATTIRO SEMPE KABUPATEN PINRANG
}

\author{
${ }^{1}$ Arsad, ${ }^{2}$ Meriem Meisyaroh Syamson \\ (1,2 Stikes Muhammadiyah Sidrap)
}

\begin{abstract}
ABSTRAK
Seiring dengan bertambahnya usia, fungsi organ tubuh akan semakin menurun sehingga menimbulkan berbagai keluhan, salah satunya xerostomia. Xerostomia disebabkan berkurangnya sekresi saliva yang dapat mengakibatkan rasa ketidaknyamanan pada rongga mulut, nyeri, peningkatan tingkat karies gigi dan infeksi mulut, serta kesulitan berbicara dan menelan makanan, sehingga asupan gizi pun menurun diikuti dengan penurunan berat badan. Keluhan-keluhan yang muncul ini dapat mempengaruhi kesehatan gigi dan rongga mulut yang nantinya diperkirakan dapat mempengaruhi tingkat kualitas hidup. Tujuan untuk menjelaskan pengaruh xerostomia terhadap kesehatan gigi dan mulut terkait kualitas hidup pada lansia. Metode penelitian ini merupakan penelitian observasional analitik dengan pendekatan cross-sectional design. Pengambilan sampel dengan metode purposive sampling. Subjek penelitian adalah lansia berumur $\geq 60$ tahun dengan besar sampel 107 responden untuk masing-masing kelompok. Data yang diperoleh berupa status xerostomia (diagnosa xerostomia secara subjektif) dan data kesehatan gigi dan mulut terkait kualitas hidup (dengan kuesioner OHIP-14). Uji statistik menggunakan uji normalitas uji normalitas Independent Sample Test. Hasil diperoleh rata-rata skor OHIP-14 pada kelompok lansia dengan xerostomia lebih tinggi dibandingkan dengan kelompok lansia tanpa xerostomia. Hal ini menunjukkan bahwa kualitas hidup terkait kesehatan gigi dan mulut kelompok usila dengan xerostomia cenderung lebih rendah dibandingkan dengan kelompok lansia tanpa xerostomia. Uji One-Sample Kolmogorov-Smirnov Test hasil $(0,025)$ dan analisis dilanjutkan menggunakan uji normalitas Independent Sample Test $(0,000)$ diperoleh perbedaan yang signifikan $(p<0,05)$.
\end{abstract}

Kata Kunci: Xerostomia, Kesehatan Gigi, Kualitas Hidup, Lansia

\section{PENDAHULUAN}

Indonesia merupakan salah satu negara berkembang yang berhasil dalam pembangunan bidang kependudukan, keluarga berencana dan kesehatan. Keberhasilan yang menonjol salah satunya adalah semakin meningkatnya usia harapan hidup penduduk Indonesia. Seiring dengan meningkatnya usia harapan hidup penduduk Indonesia, maka populasi penduduk lansia juga akan meningkat. Tahun 2010 terdapat 24 juta jiwa penduduk lansia atau hampir 10 persen dari seluruh jumlah penduduk Indonesia dan pada tahun 2020 jumlah penduduk lansia (lanjut usia) di Indonesia diperkirakan mencapai 11,34 persen dari jumlah penduduk yaitu sekitar 28,8 juta jiwa. (BPS, 2013)

$$
\text { Proporsi Penduduk yang }
$$

Bermasalah Gigi dan Mulut serta Telah
Menerima Perawatan dari Tenaga Medis Gigi menurut Karakteristik, Riskesdas 2018 Bermasalah gigi \& Mulut Kelompok umur $(\mathrm{WHO})>65$ + tahun $(54,2 \%), 95 \% \mathrm{Cl}(53,5-$ 54,8). Proporsi Tindakan untuk Mengatasi Masalah Gigi dan Mulut menurut Provinsi, Riskesdas 2018. Dalam 1 tahun terakhir jenis tindakan yang diterima untuk mengatasi masalah gigi \& mulut. Konseling perawatan kebersihan dan kesehatan gigi \& mulut Sulawesi Selatan (4,9\%), 95\% Cl $(4,5-5,3)$. (Riskesdas, 2018)

Saliva berperan penting bagi kesehatan rongga mulut. Fungsi saliva yang penting dan sangat jelas yaitu saat makan, untuk mengecap dan menjadi pelumas bagi makanan dan melindungi mukosa dan gigi. Air, musin, dan glikoprotein kaya-proline menjadi pelumas bagi makanan dan membantu proses menelan. Saliva juga 
penting untuk persepsi rasa yang normal. Saliva berfungsi protektif melalui berbagai komponen antimikrobial seperti musin, histatin, lisozim, dan laktoferin, dan melalu antibodi spesifik terhadap mikroorganisme. (Scully C, 2012)

Pada usila terjadi proses penuaan dimana akan berdampak pada berbagai aspek kehidupan, baik sosial, ekonomi, dan terutama kesehatan, hal ini dikarenakan dengan semakin bertambahnya usia, fungsi organ tubuh akan semakin menurun (degenerasi organ) baik karena faktor alamiah maupun karena penyakit, (Kemeneg, 2012). Salah satu hal yang terkait dengan degenerasi pada usila adalah keluhan mulut kering (xerostomia). Keadaan ini disebabkan karena terjadi atropi pada kelenjar saliva yang akan menurunkan produksi saliva dan mengubah komposisinya. (Sonis ST, 1995)

Lebih dari $30 \%$ populasi berumur 65 tahun mengalami gejala ini dan $14-40 \%$ orang dewasa juga mengalaminya, (Ship JA, 2003). Berkurangnya sekresi air liur/saliva ini dapat mengakibatkan rasa ketidaknyamanan pada rongga mulut, nyeri, peningkatan tingkat karies gigi dan infeksi mulut, serta kesulitan berbicara dan menelan makanan, sehingga asupan gizi pun menurun diikuti dengan penurunan berat badan. Keluhan-keluhan yang muncul akibat xerostomia ini dapat mempengaruhi kesehatan gigi dan rongga mulut yang nantinya akan mempengaruhi tingkat kualitas hidup pula. (Eugene, 2007)

Adapun data Kependudukan dan Catatan Sipil Kabupaten Pinrang pada tahun 2017 dengan jumlah penduduk 408.582 jiwa dan salah satunya Kecamatan Mattiro Sompe 30.117 Jiwa. Dari data kependudukan dan catatan sipil kabupaten Pinrang pada tahun 2017 dengan jumlah 408.582 jiwa dimana terdapat 42.454 jiwa yang di atas umur 60 tahun tau lansia, sedangkan jumlah penduduk di desa mattombong kecamatan matiroseompe kurang lebih 2.400 jiwa, adapun yang berumur lansia atau 60 tahun keatas, menurut keterangan kepala desa sekitar 10\%. (Capil Pinrang, 2017)

Berdasarkan uraian diatas, dengan adanya populasi usila yang terus meningkat, diharapkan kualitas hidup juga tetap optimal. Akan tetapi penelitian mengenai menganalisis xerostomia terhadap kualitas hidup pada usila di Indonesia belum pernah diungkap sehingga penulis tertarik untuk meneliti pengaruh xerostomia terhadap kesehatan gigi dan mulut terkait kualitas hidup pada usila.

Xerostomia (mulut kering) adalah komplain subjektif dari mulut kering yang bisa disebabkan oleh penurunan produksi saliva. Efek samping obat Obat-obat ini memiliki sifat antikolinergik atau simpatomimetik yang akan menurunkan produksi saliva sehingga kadar asam di dalam mulut meningkat. Dengan jumlah yang sedikit dan konsistensi yang kental, saliva akan kehilangan fungsinya sebagai pembersih alami rongga mulut, (Ramadhan AG, 2010).

Tingkat radiasi dapat mengakibatkan rusaknya struktur kelenjar saliva dengan Terapi radiasi pada daerah leher dan kepala untuk perawatan kanker telah terbukti berbagai derajat kerusakan pada kelenjar saliva yang terkena radioterapi. Volume kelenjar saliva. Ada beberapa penyakit lokal tertentu yang mempengaruhi kelenjar saliva dan menyebabkan berkurangnya aliran saliva Penyakit ini menyebabkan degenerasi dari sel asini dan penyumbatan duktus. Kista-kista dan tumor kelenjar saliva, baik yang jinak maupun ganas dapat menyebabkan penekanan pada struktur- struktur duktus dari 
kelenjar saliva dan dengan demikian mempengaruhi sekresi saliva. (Hasibuan S, 2012)

Tingkat umur, keadaan ini disebabkan oleh adanya perubahan atropi pada kelenjar saliva sesuai dengan pertambahan umur yang akan menurunkan produksi saliva dan mengubah komposisinya. Seiring dengan meningkatnya usia, terjadi proses aging. Terjadi perubahan dan kemunduran fungsi kelenjar saliva, dimana kelenjar parenkim hilang dan akan digantikan oleh jaringan ikat dan lemak. Keadaan ini mengakibatkan pengurangan jumlah aliran saliva. (Hasibuan S, 2012)

Tingkat stress, pada saat berolah raga, atau berbicara yang lama dapat menyebabkan berkurangnya aliran saliva sehingga mulut terasa kering. Dalam keadaan gangguan emosional seperti stres, putus asa dan rasa takut dapat merangsang terjadinya pengaruh simpatik dari sistem saraf autonom dan menghalangi sistem saraf parasimpatik sehingga sekresi saliva menjadi menurun dan menyebabkan mulut menjadi kering. Bernafas melalui mulut juga akan memberikan pengaruh mulut kering. (Hasibuan S, 2012)

Individu yang menderita xerostomia sering mengeluhkan masalah dalam makan, berbicara, menelan, dan pemakaian gigi tiruan. Makanan yang kering biasanya sulit dikunyah dan ditelan. Pemakaian gigi tiruan juga mengalami masalah dengan retensi gigi tiruan, lesi akibat gigi tiruan, dan lidah juga lengket pada palatum. Xerostomia menyebabkan mengeringnya selaput lendir. Mukosa mulut menjadi kering, mudah mengalami iritasi dan infeksi. Keadaan ini disebabkan oleh karena tidak adanya daya lubrikasi dan proteksi dari saliva. Rasa pengecapan dan proses berbicara juga akan terganggu. Kekeringan pada mulut menyebabkan fungsi pembersih saliva berkurang, sehingga terjadi radang dari selaput lendir yang disertai keluhan mulut terasa seperti terbakar. Selain itu, fungsi bakteriose dari saliva pada penderita xerostomia akan berkurang sehingga menyebabkan timbulnya proses karies gigi. (Bartels CL, 2012)

Salah satu instrumen yang sering digunakan untuk mengukur kesehatan gigi dan mulut terkait kualitas hidup adalah Oral Health Impact Propile (OHIP). OHIP yang dikembangkan oleh slade GD dan Spencer AJ pada tahun 1994 ini, terdiri dari 49 butir pertanyaan yang berhubungan dengan tujuh dimensi dengan, dimana tujuh dimensi tersebut merupakan dampak akibat kelainan gigi dan mulut yang nantinya akan mempengaruhi kualitas hidup. Tujuh dimensi tersebut yaitu: keterbatasan fungsi, rasa sakit fisik, ketidaknyamanan psikis, ketidakmampuan sosial dan handikap. OHIP ini memilki lima skala likert yaitu: $0=$ tidak pernah, 1 = sangat jarang, 2 = kadangkadang, 3 = sering, dan $4=$ sangat sering (Slade \& Spencer, 2015)

Pertanyaan pada OHIP-14 ini ditanyakan seberapa sering dialami dalam satu bulan terakhir berkaitan dengan keluhan pada gigi, rongga mulut dan atau struktur terkait. Apabila terdapat tiga atau lebih pertanyaan OHIP-14 yang tidak dijawab atau dijawab tidak tahu, maka OHIP-14 tidak dapat digunakan dalam analisis (Rusanen \& Jaana, 2009).

\section{METODE PENELITIAN}

Metode penelitian yang digunakan adalah observasional analitik dengan pendekatan belah lintang (cross sectional). 
Populasi target penelitian ini adalah seluruh usila di Desa Mattombong Kecamatan Mattiro Sempe Kabupaten Pinrang yang berjumlah 240 orang.

Pada penelitian ini sampel yang diambil adalah semua lansia di Desa Mattombong Kecamatan Mattiro Sempe Kabupaten Pinrang yang memenuhi kriteria inklusi.

\section{Cara Kerja}

1. Menyeleksi subjek penelitian sesuai kriteria inklusi dan eksklusi.

2. Meminta kesediaan subjek penelitian melalui informed consent.

3. Melakukan anamnesis pada usila untuk mendignosa xerostomia secara subjektif berdasarkan pertanyaan "seberapa sering Anda merasa mulut anda kering ?" dengan pilihan jawaban "selalu sering, kadang-kadang, tidak pernah". Untuk responden yang memberikan jawaban "selalu" dan "sering" dikategorikan xerostomia (kode 0) sedangkan yang lainnya dikategorikan bukan xerostomia (kode 1).

4. Pengisian kuesioner Oral Health Impact Profile-14 (OHIP-14)

5. Pengolahan data yang sudah terkumpul menggunakan komputer.

6. Melakukan analisis data.
7. Menyusun penulisan hasil analisis data dalam bentuk laporan hasil penelitian.

HASIL

Saliva berperan penting bagi kesehatan rongga mulut. Fungsi saliva yang penting dan sangat jelas yaitu saat makan, untuk mengecap dan menjadi pelumas bagi makanan dan melindungi mukosa dan gigi. Air, musin, dan glikoprotein kaya-proline menjadi pelumas bagi makanan dan membantu proses menelan. Saliva juga penting untuk persepsi rasa yang normal. Saliva berfungsi protektif melalui berbagai komponen antimikrobial seperti musin, histatin, lisozim, dan laktoferin, dan melalui antibodi spesifik terhadap mikroorganisme.

Setelah dilakukan pengambilan data, kemudian dilakukan pengolahan untuk memperoleh hasil penelitian, berikut ini peneliti menyajikan hasi analisa univariat tiap Variabel dalam bentuk tabel distribusi frekuensi, analisa bivariat untuk mengetahui hubungan antara Variabel dependen dan Variabel independen dengan menggunakan uji statistik Analisis Regresi Berganda. Keseluruhan pengolahan data pada penelitian ini menggunakan program Statistical For Social Science (SPSS) Versi 16.00 For Windows.

Karakteristik Dasar Subjek Penelitian

Tabel 1 Distribusi umur dan jenis kelamin subjek penelitian menurut status xerostomia

\begin{tabular}{|c|c|c|c|c|}
\hline \multirow{2}{*}{ Umur (thn) } & \multicolumn{2}{|c|}{ Xerostomia } & \multirow{2}{*}{ Total } & \multirow{3}{*}{$\begin{array}{l}\text { Min-Max } \\
=60-90 \\
\quad \text { Mean } \pm S D\end{array}$} \\
\hline & Ya & Tidak & & \\
\hline Usila (60-75) & 26 (24.3\%) & 54 (50.5\%) & $80(74.8 \%)$ & \\
\hline Jenis Kelamin & & & & \\
\hline Laki-laki & 18 (16.8\%) & 45 (42.1\%) & 63 (58.9\%) & 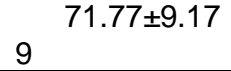 \\
\hline Perempuan & $8(7.5 \%)$ & 36 (33.6\%) & $44(41.1 \%)$ & \\
\hline
\end{tabular}

Tabel 1 menunjukkan bahwa ratarata usia subjek penelitian $71,77( \pm 7.700)$ tahun. Sebagian besar subjek penelitian adalah responden yang termasuk pada kelompok usila (24.3\%). Sedangkan untuk jenis kelamin, responden mayoritas berjenis 
kelamin laki-laki berjumlah 63 responden Untuk xerostomia sendiri lebih banyak terjadi pada usila laki-laki $(16,8 \%)$.

Skor Oral Health Impact Profile-14 (OHIP. 14)

Skor OHIP-14 digunakan dalam penelitian ini untuk menilai kesehatan gigi dan mulut terkait kualitas hidup pada usila. Hasil pengumpulan data OHIP-14 pada subjek penelitian sebaga berikut :

\section{Distribusi frekuensi keluhan usila} berdasarkan kuesioner OHIP-14

Menunjukkan pada dimensi kualitas hidup keterbatasan fungsi, sebagian besar responden $(52,3 \%)$ sering mengalam keterbatasan mengucapkan kata-kata dan sebagian besar respoden (46,7\%) juga tidak dapat mengecap rasa dengan baik.

Pada dimensi kualitas hidup yang ke-2 yaitu rasa sakit fisik, sebagian responden yaitu sekitar (38,3\%) sering merasakan sakit pada rongga mulut, dan $(42,1 \%)$ responden sering tidak nyaman ketika mengunyah makanan.

Lalu pada dimensi kualitas hidup ketidaknyamanan psikis, sebagian besar responden $(37,4 \%)$ sangat sering merasa khawatir karena permasalahan di rongga mulut mereka dan sebagian responden $(39,3 \%)$ sering merasa tegang karena permasalahan di rongga mulut mereka.

Pada dimensi kualitas hidup ketidakmampuan fisik, terdapat (55.1\%) responden sering merasa jumlah makanan yang dikonsumsi kurang memuaskan, dan $(46.7 \%)$ responden sangat sering terhenti saat makan.
Pada dimensi kualitas hidup selanjutnya yaitu, sebanyak (65.4\%) responden sering kesulitan merasa rileks karena permasalahan pada rongga mulut mereka, dan $(65.4 \%)$ responden sering merasa malu karena permasalahan pada rongga mulut mereka.

Pada dimensi kualitas hidup ketidakmampuan sosial, sebagian besar responden (32.7\%) sangat sering mudah tersinggung karena permasalahan rongga mulut mereka, dan sekitar (32.7\%) responden kadang-kadang kesulitan melakukan kegiatan sehari-hari karena permasalahan pada rongga mulut mereka.

Dan yang terakhir pada dimensi kualitas hidup (handicap), sebagian besar responden (49.5\%) sering merasa hidup kurang memuaskan karena permaslahan rongga mulut mereka, dan (55.1\%) responden susah untuk melakukan apapun karena permasalahan pada rongga mulut mereka.

\section{Analisis Inferensia}

Data yang diperoleh dalam penelitian ini berupa data primer yaitu data kondisi mulut kering yang diperoleh dari diagnosa xerostomia secara subjektif dan data kesehatan gigi dan mulut terkait dengan kualitas hidup yang diperoleh dari pemberian kuesioner OHIP-14 kepada responden penelitian. Untuk data xerostomia dinyatakan dalam skala rasio yaitu skor total OHIP-14 yang dihitung perdimensi kualitas hidup maupun secara keseluruhan yang kemudian dikelompokkan menurut status xerostomia dan non xerostomia. 
Tabel 2 Hasil perhitungan uji Kolmogorov test

\begin{tabular}{llr}
\hline \multicolumn{2}{l}{ One-Sample Kolmogorov-Smirnov Test } & \\
\hline $\mathrm{N}$ & & Unstandardized Residual \\
\hline Normal Parameters ${ }^{\mathrm{a}, \mathrm{b}}$ & Mean & 107 \\
& Std. Deviation & .0000000 \\
\hline \multirow{2}{*}{ Most Extreme Differences } & Absolute & .20920934 \\
\cline { 2 - 3 } & Positive & .143 \\
\cline { 2 - 3 } & Negative & .143 \\
\hline Kolmogorov-Smirnov Z & & 1.104 \\
\hline Asymp. Sig. (2-tailed) & & .481 \\
\hline
\end{tabular}

Berdasarkan hasil uji normalitas dengan menggunakan uji Kolmogrov-Smirnov $(n>50)$, diperoleh distribusi data skor OHIP-14 total $(p=0,025)$. Proses transformasi data skor
OHIP-14 pada kelompok usila tanpa xerostomia ternyata tetap menghasilkan sebaran data yang tidak normal.

Tabel 3 Hasil perhitungan uji normalitas Independent Sample Test berdasarkan skor OHIP14 per dimensi kualitas hidup

\begin{tabular}{llcc}
\hline $\begin{array}{c}\text { Dimensi Kualitas } \\
\text { Hidup }\end{array}$ & $\begin{array}{c}\text { Skor OHIP-14 per } \\
\text { dimensi }\end{array}$ & $\begin{array}{c}\mathbf{N} \\
\text { (Orang) }\end{array}$ & $\mathbf{p}$ \\
\hline Keterbatasan fungsi & Xerostomia & 26 & 0,000 \\
\hline & Tidak Xerostomia & 81 & 0,000 \\
\hline Rasa sakit fisik & Xerostomia & 26 & 0,000 \\
\hline & Tidak xerostomia & 81 & 0,000 \\
\hline Ketidaknyamanan Psikis & Xerostomia & 26 & 0,000 \\
\hline & Tidak Xerostomia & 81 & 0,000 \\
\hline Ketidakmampuan fisik & Xerostomia & 26 & 0,000 \\
\hline & Tidak Xerostomia & 81 & 0,000 \\
\hline Ketidakmampuan psikis & Xerostomia & 26 & 0,000 \\
\hline Ketidakmampuan sosial & Tidak Xerostomia & 81 & 0,000 \\
\hline & Xerostomia & 26 & 0,000 \\
\hline Handikap & Tidak Xerostomia & 81 & 0,000 \\
\hline & Xerostomia & 26 & 0,000 \\
\hline & Tidak Xerostomia & 81 & 0,000 \\
\hline
\end{tabular}

Berdasarkan table 5.3 uji normalitas Independent Sample Test diketahui nilai Sig. (2-tailed) sebesar $0,000<0,05$ maka sebagian dasar pengambilan keputusan dalam uji independent sample test dapat disimpulkan bahwa ada perbedaan yang signifikan (nyata) antara xerostomia dan tidak xerostomia pada kualitas hidup lansia.

$$
\text { Dari table tersebut juga }
$$
menunjukkan rata-rata skor OHIP-14 total pada kelompok lansia dengan tidak xerostomia lebih tinggi dibandingkan dengan skor OHIP-14 total pada kelompok lansia dengan xerostomia. Skor OHIP-14 yang semakin tinggi menunjukkan kualitas hidup yang semakin rendah. Hal ini menunjukkan bahwa kualitas hidup kelompok lansia dengan xerostomia lebih rendah dibandingkan dengan kelompok lansia tanpa xerostomia.

\section{PEMBAHASAN}

Sekresi saliva berlangsung sebanyak 1-2 liter setiap harinya dengan laju sekresi 0,5-5-6 ml/menit. Derajat keasaman atau $\mathrm{pH}$ saliva normal berkisar antara 6,7-7,3. 
$\mathrm{pH}$ saliva tergantung pada perbandingan asam dan konjugasi basanya.( Novia, dkk, 2017).

Perubahan dan kemunduran fungsi kelenjar saliva terjadi seiring dengan meningkatnya usia, dimana kelenjar parenkim akan hilang dan digantikan oleh jaringan ikat dan jaringan lemak. Keadaan ini mengakibatkan pengurangan jumlah aliran saliva. (Soni ST dkk, 1995). Hal ini diperkuat dari hasil penelitian ini yang menemukan prevalensi xerostomia lebih tinggi pada lansia (60-75) tahun sebanyak $24.3 \%$ dibandingkan pada lansia (75-90), dan yang paling banyak berjenis laki-laki sebanyak $16.8 \%$. Temuan ini juga menunjukkan kesesuaian dengan teori yang menyatakan $14-40 \%$ orang dewasa mengalami xerostomia (Ship JA, 2003). Temuan penelitian ini dapat membuktikan teori yang menyatakan bahwa pada usia lanjut, xerostomia merupakan masalah umum yang banyak terjadi (Pajukoski $H$, 2001). Penelitian ini juga sejalan dengan (Amelia, 2012) menyatakan bahwa telah menemukan prevalensi xerostomia lebih tinggi pada usila tua (75-90 tahun) yaitu sebanyak $26,8 \%$.

Xerostomia terjadi karena perubahan atropi pada kelenjar saliva terkait dengan degenerasi akibat proses aging. Kemunduran fungsi kelenjar saliva terjadi akibat hilangnya kelenjar parenkim yang digantikan oleh jaringan ikat dan lemak. Keadaan ini mengakibatkan pengurangan jumlah aliran saliva (Hasibuan, 2012). Pertambahan usia juga berdampak pada atropik pada kelenjar submandibular yang juga berkontribusi pada penurunan reproduksi dan perubahan komposisi saliva (Kidd, 1992).
Sekresi air/liur yang berkurang dapat menyebabkan rasa ketidaknyamanan pada rongga mulut, nyeri, peningkatan tingkat karies dan infeksi mulut, serta kesulitan berbicara dan menelan makanan. Keluhan-keluhan yang muncul akibat xerostomia ini dapat mempengaruhi kesehatan gigi dan rongga mulut yang selanjutnya berpengaruh terhadap tingkat kualitas hidup (Eugene, 2007).

Secara statistik, penelitian ini menunjukkan perbedaan yang bermakna pada skor OHIP-14 menurut status xerostomia dan non xerostomia, yang artinya xerostomia memberikan kontribusi pengaruh pada kualitas hidup terkait kesehatan gigi dan mulut pada usila. Hasil penelitian ini didukung oleh penelitian sebelumnya yang dilakukan oleh Thomson et.al (2006) yang menunjukkan ada hubungan kuat antara xerostomia dan OHRQoL (di semua domain OHIP-14). Hasil yang sama juga diperoleh dari penelitian ini, yaitu didapatkan perbedaan yang signifikan pada semua dimensi kualitas hidup dalam index OHIP-14 terhadap kelompok lansia dengan xerostomia dan tanpa xerostomia. Kualitas hidup per dimensi pada kelompok lansia dengan xerostomia pun cenderung lebih rendah dibandingkan dengan kualitas hidup kelompok lansia tanpa xerostomia.

\section{KESIMPULAN}

Dari penelitian yang dilakukan pada 107 subjek penelitian, diperoleh hasil adanya perbedaan bermakna dari uji analisis statistik terhadap skor OHIP-14 menurut ststus xerostomia. Dengan demikian dapat disimpulkan bahwa xerostomia berpengaruh terhadap kesehatan gigi dan mulut terkait kualitas hidup pada lansia. Selain itu, dari 
penelitian ini juga diketahui rata-rata skor OHIP-14 pada kelompok usila dengan xerostomia lebih tinggi dibandingkan dengan skor OHIP-14 pada kelompok usila tanpa xerostomia. Hal ini menunjukkan bahwa kualitas hidup terkait kesehatan gigi dan mulut kelompok usila dengan xerostomia cenderung lebih rendah dibandingkan dengan kelompok usila tanpa xerostomia.

\section{SARAN}

Dari hasil penelitian tersebut di atas perlu perhatian dan pencegahat sehingga penyakit xerostomia dapat di atasi. bagi penderita xerostomia yang mempengaruhi kesehatan gigi terkait kualitas hidup perluh pemeriksaan lebih lanjut untuk menjamin kualitas hidup dimana setiap lansia yang mengalami xerostoia di sarankan untuk memeriksakan diri ketenaga kesehatan atau puskesmas terdekat.

\section{DAFTAR PUSTAKA}

Badan Perencanaan Pembangunan Nasional. Proyeksi penduduk indonesia 2010-2035. Jakarta: BPS, 2013: 6-7.

Bartels CL. Xerostomia Information for Dentists: helping patients with dry mouth 2010. $<$ ittp://oralcancerfoundation.org/den tal/xerostomia.htm $>$ (2

Data dinas kependudukan dan catatan sipil kabupaten pinrang 2017

Eugene NM, Robert LF. 2007. Salivary gland disorders. New York: Springer Bernir

Fox PC, Grisius MM. Salivary gland diseases. Burket's Oral Medicine Diagnosis and Treatment. 10th ed. Hamilton. BC Decker Inc. 2003: 235-38

GD Slade and AJ, Spencer. NCBI. Pubmed.hov.[online] [cited: juni 16,
2012] http://www.ncbi.nlm.nih. gov/pubmed/8193981

Hasibuan S. Keluhan Mulut Ditinjau dari Faktor Penyebab Manifestasi dan Penanggulangannya. (22 Juni 2015)

Johansson AK, Johansson A, Unell L, et al. A 15-yr longitudinal study of xerostomia in a Swedish population of 50-yr-old subjects. Eur J Oral Sci. 2009; 117 (1) :13-19.

Novia Khoerunnisa, Farah Hendara Ningrum, Ch. Nawangsih P. Hubungan Derajat Xerostomia Dengan $\mathrm{Ph}$ Saliva Pasca Radioterapi Kanker Kepala Leher, Jurnal Kedokteran Diponegoro Volume 6, Nomor 2, April 2017

Manurung Amelia Kusuma Wardani, Pengaruh Xerostomia Terhadap Kesehatan Gigi Dan Mulut Terkait Kualitas Hidup Pada Usila. Semarang, 26 Juli 2012

Mohammad Ar. Xerostomia In The Geriatric Patient: A New Challenge For The Oral Health Professional. A Review. Dental Forum/1/2005/Xxxiii, 67-72.

Mostofsky, David I, Forgione, Alber G. And Giddon, Donald B. Behavioral Dentistry. Usa: Blacwell. Munksgard, 2006.

Rahmadan Ag. Serba Serbi Kesehatan Gigi Dan Mulut Cetakan Pertama. Jakarta: Penerbit Bukune. 2010: 15

Rusanen, Jaana, Et Al. Quality Of Life In Patient With Severe Malocclusion Before Treatment. Finlandia: Europian Journal Of Orthodontics. 2009

Scully C, Felix Dh. Oral Medicine: Update For Dental Practitioners. [Internet]. Available At: Url: Http://Www.Bdj.Org.Accessedon 19 September 2010. Accessed On 22 Juni 2015.

Ship Ja, Pillmer Sr, Baum Bj. Xerostomia And The Geriatric Patient. J Am Geriatric Soc.2002: 50(3): 535-543.

Sonis. St, Fazio Rc, Fang L. Principles And Practice Or Oral Medicine Ed. Ke2. W.B. Philandelphia: Saunders Company. 1995: 4c7,462,465-466 